\title{
Mário Melo e suas histórias dentro da História
}

\author{
Mario Melo and their stories with in the History
}

Resumo: Este artigo pretende dar visibilidade a trajetória intelectual do historiador pernambucano Mário Melo (1884-1959), buscando ressaltar a sua participação no Instituto Arqueológico Histórico Geográfico Pernambucano (IAHGP), principal rede de sociabilidade em que estava inserido e lócus central de sua produção historiográfica. Além disso, o artigo também tem o interesse de apresentar análises de algumas de suas narrativas históricas escritas nos periódicos, meios de grande divulgação do conhecimento histórico, além de focarmos também na sua produção em formato de livro.

Palavras-chave: Mário Melo, Instituto Arqueológico Histórico Geográfico Pernambucano, Imprensa, Intelectuais, Pernambuco.

\author{
Amanda Alves Miranda Cavalcanti \\ Mestranda em História pela \\ Universidade Federal do Estado Rio de Janeiro \\ amandacavalcantil@hotmail.com
}

\begin{abstract}
This article aims to give visibility to intellectual trajectory of Pernambuco historian Mario Melo (1884-1959), trying to highlight yours participation in Instituto Arqueológico Histórico Geográfico Pernambucano (IAHGP), the major group of sociability that was inserted and central locus of his historical production. Also, the article would like show analysis of some written historical narrative in periodicals ways of disseminating of knowledge. Also, we will focus on production of the book.

Keywords: Mário Melo, Historian, Histórico Geográfico Pernambucano, Imprensa, Intellectuals, Pernambuco.
\end{abstract}


Cadê Mário Melo?/Partiu para a eternidade/ Deixando na sua cidade/Um mundo de saudade sem igual/Foliões, a nossa reverência /À sua grande ausência/No nosso carnaval/De braços para o alto/Cabelos desgrenhados/Frevando sem parar/Lá vem Mário...[...]

(PARAÍSO, 1997:125).

Muitos foliões, a partir da década de 1960, passaram a cantar este frevo de bloco criado por Nelson Ferreira, um compositor recifense, em homenagem ao finado Mário Melo, que morreu em 1959, deixando o Recife, sem suas contribuições jornalísticas e sem seus singelos "passinhos de carnaval". Foi na madrugada do dia 24 de maio de 1959 que morreu, pela terceira e última vez", o considerado, "homem de sete instrumentos", 2 como afirmam seus biógrafos, deixando a cidade órfã das polêmicas que iniciava nas páginas dos jornais.

Para se entender a consagração desse personagem, e o que o fez render tantas biografias e homenagens após sua morte, é necessário recorrer aos caminhos de sua trajetória, desde as relações familiares na infância, até os meandros de suas redes profissionais.

Mário Melo traçou a sua trajetória permeando caminhos estreitos do rigor na pesquisa histórica, acreditando que pensar e escrever sobre história seria narrar o real, o vivido, na iniciativa de prová-lo cientificamente através da análise minuciosa dos vestígios do passado. "Os capítulos deste volume são rigorosamente históricos, como em muitos o indicam as fontes. São histórias rigorosamente enquadradas na História, perfeitamente Dentro da História" (MELO, 1931a: 1).

Intelectual que viveu e atuou como intelectual durante a primeira metade do século XX, tempos de grandes transformações político-sociais, já que a República é proclamada, tendo o país à necessidade de criar novos fundamentos políticos. Surgiu assim, a preocupação de se criar um novo projeto político-ideológico que servisse para garantir a sobrevivência do novo regime implantado. Além da República, nos anos

\footnotetext{
${ }^{1}$ Sua morte foi declarada três vezes nos jornais, a primeira foi em 1907, logo após seu casamento, quando contraiu febre tifoide e foi dado como morto pela imprensa. A segunda foi em 1951, quando se espalhou a notícia falsa que havia morrido, chegando aos ouvidos do seu amigo e ex-interventor de Pernambuco, Agamenon Magalhães, que procurou apurar sobre a falsa declaração. E a terceira foi em 1959, mas desta vez, Mário Melo não escapou da morte. (PARAÍSO, 1997: 158)

${ }^{2}$ Segundo seus biógrafos, ele pode ser considerado jornalista, historiador, telegrafista, político, professor, músico, geógrafo, poeta, folclorista, folião, sendo, portanto, um intelectual múltiplo, como era de costume entre os intelectuais nas primeiras décadas do século XX.
} 
finais da década de 1880, a escravidão também foi abolida, trazendo problemas sociais para a nova ordem política. Questões relacionadas ao que fazer com a grande massa de homens pobres e livres, que inchavam os centros urbanos do país, e como incorporá-los ao novo projeto de nação era muito comum nos meios intelectuais da época.

Nos cafés, restaurantes, e salões estes intelectuais discutiam a melhor forma de promover o desenvolvimento do Brasil, com as perspectivas sempre voltadas para a promoção de um futuro melhor para o país. Questões relacionadas à identidade, raça, nação e progresso foram bastante debatidas e passaram a ganhar um novo sentido, sendo respaldadas por pressupostos liberais, evolucionistas, cientificistas e positivistas. A partir dessas ideias que permeavam os espaços de sociabilidade da época, os grupos intelectuais, iram se preocupar em pensar esse novo projeto político-ideológico para o país, na intenção de legitimar a nova ordem instalada, focando, principalmente, nas questões que envolviam a problemática da identidade nacional. O grande interesse era estimular um sentimento de pertencimento na nação de forma que transformasse o imenso aglomerado de diferentes grupos que formavam o Brasil em uma população "unida" e "ordeira".

A preocupação com a grande massa de desvalidos sociais faz surgir uma ressignificação da ideia de "povo", já que agora passariam a ser incorporados à nação. Para pensar o projeto de construção de nação, podemos dizer que, mais que inventadas, as nações são imaginadas, a partir da criação de um sentimento fraterno entre os indivíduos, fazendo sentido para a "alma", "construindo-se em tempos vazios e homogêneos". Elas são imaginadas como comunidades, na medida em que sempre se concebem a partir da "camaradagem horizontal", sendo estabelecida a ideia de um “nós" coletivo, irmanando relações em tudo distintas (ANDERSON, 2008, p. 10)

A escolha do que se pretendia identificar como constituinte da nação, nas primeiras décadas do século XX, resultou na seleção de elementos pertencentes a um passado comum, uma história remota e originária dos preceitos republicanos. Nesse sentido, para que fosse estimulado o sentimento de unidade e pertencimento à nação brasileira houve a necessidade de que a História do Brasil fosse recontada de maneira que legitimasse o novo regime político instalado, por meio da busca nos antepassados coloniais e imperiais os ímpetos republicanos. Isto é, a exaltação do passado, que os "grandes heróis" encarnavam, tornava-se instrumento essencial para a produção e reprodução de uma nova memória nacional. Portanto, como afirma Georges Balandier: 
A estratégia do passado, desenvolvida com fins políticos, apresenta-se sob dois aspectos aparentemente contraditórios; pode ser posta ao serviço da ordem social existente e das posições adquiridas, ou servir a ambição daqueles que pretendem conquistar a autoridade e legitimá-la (1969: 122).

O novo foi, portanto, "historicizado", havendo a necessidade de se promover estratégias políticas de memória interessadas em socializar certa seleção do passado. (CATROGA, 2005). Como salienta Angela de Castro Gomes, a construção de uma história ou memória nacional nunca parte de uma folha de papel em branco, arbitrária ou ingênua, sendo resultado de negociações e apropriações das tradições (1996). Assim, foi construída uma nova cultura histórica ${ }^{3}$, partindo agora de premissas republicanas, que, além da restruturação da escrita da história, também necessitou, com urgência, de uma readequação dos "heróis", eventos, e junto a eles, uma reconfiguração dos monumentos, das bandeiras, dos hinos, das comemorações cívicas a fím de que se adequem às novas demandas políticas. Portanto, as necessidades do presente ditariam as regras nesse processo de reinvindicação dos símbolos nacionais, com vistas à construção de identidades.

Os grandes protagonistas dessa construção da cultura política republicana que se instaurou nessas primeiras décadas do século XX foram os intelectuais, categoria que não possui contornos muito rígidos para a sua definição, formando, portanto, um grupo multifacetado. Esse "pequeno mundo estreito" seria o responsável por produzir e mediar às interpretações da realidade social brasileira, sendo composto por atores políticos do campo da cultura. ${ }^{4}$ Além disso, os intelectuais eram essenciais à legitimação de regimes políticos modernos, exercendo o papel de produtores de bens culturais e simbólicos, por meio de suportes duradouros (como o livro) ou efêmeros (como os artigos de jornais, ou

\footnotetext{
${ }^{3}$ Segundo a historiadora Angela de Castro Gomes, o conceito de cultura histórica está intrinsecamente relacionado ao de cultura política, que é entendido como um "sistema de representações, complexo e heterogêneo" capaz de permitir a compreensão dos sentidos que um determinado grupo atribui a uma dada realidade social, em determinado momento e lugar. Desse modo, ela vai dizer que a cultura história desenvolvida em determinado momento é uma estratégia de uma cultura política que se deseja estimular. Vale lembrar que há em um momento histórico várias culturas históricas em disputa, mas apenas uma é enquadrada e propagada (GOMES, 2007, pp. 44-64)

${ }^{4}$ A categoria de intelectuais utilizada neste artigo parte das ideias de Jean-François Sirinelli, que vai adentrar-se nas discussões da História dos intelectuais, debates esses que permeiam a década de 1980 e que está inserido nas discussões da retomada da história política. Este historiador francês procura traçar uma metodologia eficaz para a operacionalização articulada entre o campo intelectual e a defesa política, tendo como ponto de partida conceitos-chaves como o de itinerário, de geração, e de sociabilidade. (SIRINELLI, 1996)
} 
discursos). Eles eram homens que se movimentavam entre as fronteiras fluidas dos vários campos disciplinares, permeando os diversos lugares de sociabilidade, espaços estes com diferenciados formatos organizacionais que tinham tradições internas também muito variadas (GOMES, 2009). Esses intelectuais também comporiam redes de sociabilidades múltiplas dentro destes lugares, articulando-se entre si e compartilhando ideias e simpatias, que estimulavam um estreitamento de laços afetivos.

Para tratar dos intelectuais que constituíam as redes de sociabilidades brasileira do final do século XIX e início do XX, temos que entendê-los em função da interseção entre os campos políticos e intelectuais, percebendo-os em suas variadas ocupações e múltiplas atuações na sociedade. Pensando em um grupo específico, os historiadores ${ }^{5}$, por exemplo, seriam aqueles intelectuais responsáveis por reestruturar e reescrever a histórica do Brasil, tendo como o principal lugar de sociabilidade os institutos históricos, que se formariam em vários Estados do Brasil, ao longo do século XIX e primeira metade do século $\mathrm{XX}^{6}{ }^{6}$ Portanto, podemos dizer que, Mário Melo, o protagonista deste artigo, teve o Instituto Histórico pernambucano como o principal espaço para a construção de sua trajetória intelectual como historiador.

Mário Carneiro do Rego Melo nasceu em 5 de fevereiro de 1884, filho de Manuel do Rego Melo, um juiz federal, e de Maria da Conceição Carneiro da Cunha, "Dona Ciçone", como era conhecida, prima do ilustre abolicionista pernambucano José Mariano $^{7}$, no sítio "Barbalho", no bairro da Iputinga. Este sítio, e a casa de dona Olegarinha $^{8}$, durante as turbulências abolicionistas do final do século XIX, foram espaços nos quais abrigavam um grande número de escravos fugitivos, que de lá iriam embarcar em botes para o Ceará, onde a abolição já havia sido feita (PARAÍSO, 1997). Antes mesmo de ingressar na faculdade, cursando ainda o ginásio no Colégio Ginásio Pernambucano, ele desperta seu interesse pelo jornalismo, quando, em 1900, funda com um grupo de amigos, - entre eles estão Mário Rodrigues ${ }^{9}$, Alcebíades Lemos, Adalberto Ribeiro, Euzébio de Souza, - um centro chamado "Sociedade Literária

\footnotetext{
${ }^{5}$ Ainda não havia no Brasil, durante a primeira metade do século XX, academias de formação em História, de forma que os historiadores eram aqueles homens que faziam parte de lugares e redes de sociabilidades que se legitimavam por ter como função escrever sobre história.

${ }^{6}$ Lembrando que a disciplina histórica estava passando por processos de transformação relacionadas às práticas e ao ofício do historiador, já que fervilhavam as discussões sobre se a história era uma prática científica ou não.

${ }^{7}$ José Mariano lutou pela causa republicana e abolicionista em fins do século XIX.

${ }^{8}$ Dona Olegarinha era esposa de José Mariano, que, como "Dona Ciçone", muito atuou a favor da abolição dos escravos no Brasil. Sua casa se instalara no Poço da Panela, próxima à igreja do poço, separada da casa de Mário Melo, Sítio do "Barbalho", pelo rio Capibaribe. (PARAÍSO, 1997)

${ }^{9}$ Pai do dramaturgo Nelson Rodrigues.
} 
Bernardo Viera de Melo", no qual havia discussões que envolviam assuntos variados. Estes debates frequentemente eram divulgados em um jornal $O$ Álbum, criado pelo próprio grupo.

Ao longo da primeira metade do século XX, suas narrativas jornalísticas, caracterizadas pelos seus assíduos leitores como sempre polêmicas e marcadas pela combatividade, estavam presentes em diversos periódicos pernambucanos. Dentre os tantos periódicos onde contribuía, desatacam-se alguns, como: Diário de Pernambuco, Jornal do Commercio, Jornal Pequeno, Folha da Manhã. Ele possuía, inclusive, diversas colunas próprias nestes jornais, onde escrevia diariamente sobre assuntos variados, tratando de questões polêmicas sobre política, escrevendo crônicas sobre a vida cotidiana da cidade do Recife, e até mesmo divulgando seus textos de cunho histórico sobre temas da história de Pernambuco e do Brasil. Além disso, vale lembrar ainda de sua produção jornalística expressiva para outros veículos espalhados pelo Brasil $^{10}$, contribuindo até em jornais de outros países ${ }^{11}$.

Os periódicos eram os principais instrumentos que serviam para a disseminação da iniciativa republicana, isto é, tiveram a função de educar a população brasileira para esta nova História do Brasil que estava sendo formulada pelos historiadores. Estes, como intelectuais que eram, ao divulgarem constantemente nas páginas dos jornais suas narrativas históricas, tinham a intenção de popularizar o conhecimento histórico, formulado, principalmente, nos institutos históricos. Dessa forma, estes saberes passariam a atingir um público mais amplo, deixando de ser restrito apenas ao grupo de iniciados.

Em paralelo a sua profissão de jornalista, a principal instituição que esse sujeito se consagrou como um intelectual foi o Instituto Arqueológico Geográfico Pernambucano (IAGP). Tudo começou em 1909, quando ele tornou-se sócio da instituição. Este momento é bastante valorizado por Mário Melo, como podemos perceber em suas próprias palavras:

\footnotetext{
${ }^{10}$ Como é bastante salientado em um roteiro jornalístico sobre Mário Melo de autoria do jornalista Luiz Nascimento, ele contribuiu frequentemente vários periódicos importantes do país, nos quais, destacamos a Revista Ilustração Brasileira, publicando nela durante os anos de 1922 a 1924, o Jornal do Brasil, de 1936 e 1939, e a revista Cultura Política, publicando em 1942. (NASCIMENTO, 2012)

${ }^{11}$ Mário Melo assumiu, durante a década de 1930, o cargo de inspetor na Inspetoria Estadual dos Monumentos Nacionais de Pernambuco, órgão criado em 1929 que tinha como papel a preservação do patrimônio histórico geográfico do Brasil. Ele dirigiu a instituição até 1933. (CANTARELLI, 2012)
} 
Menino, estudante de primeiras letras, li a História da Revolução Pernambucana de 1817, do Monsenhor Muniz Tavares, encontrada na biblioteca de meu pai. Data deste tempo a minha admiração pela bravura pernambucana e constituiu-se a maior aspiração da minha vida: ser sócio do Instituto Arqueológico. Feliz acaso, porque dele me adveio extremado amor ao torrão natal, cuja história tenho procurado estudar com tanto desvelo (SOUZA, 2010, pp. 85)

Este fragmento de texto, provavelmente foi tirado de seu discurso de posse, ou seja, um momento propício para enaltecer a instituição que passou a fazer parte, procurando, em suas palavras, demostrar a vontade que tinha de tornar-se sócio. A partir deste momento, Mário Melo sofreu uma inflexão em sua vida, iniciando, assim, um processo de consagração dele como historiador, tanto que, quando morreu em 1959, o IAHGP fez uma homenagem fúnebre a ele, contando com discursos de alguns intelectuais pernambucanos. Um destes discursos fúnebres foi feito pelo escritor e teatrólogo, Valdemar de Oliveira, que fala sobre a relação de Mário Melo com a instituição: "Tão impregnado de Mário Melo estava o Instituto e tão impregnado do Instituto estava Mário Melo, que um e outro se confundiam” (PARAÍSO, 1997: 184).

O IAGP, criado em 28 de janeiro de 1862, que inicialmente se chamava "Sociedade Arqueológica Pernambucana", foi o primeiro instituto histórico regional do país. Ele foi fundado por recomendação do Imperador D. Pedro II, na intenção de que fosse criada uma instituição aos moldes do IHGB. A proposta foi a criação de um sodalício, que, além de ser um espaço de produção historiográfica, deveria conter também um museu, onde estaria presente pinturas sobre os eventos e personagens da História de Pernambuco, e bens culturais no geral, recebidos na forma de doação feita por particulares e por entidade que tinha o interesse na preservação de peças antigas. ${ }^{12}$

O grupo que impulsionou a formação da instituição era composto por seis homens - Joaquim Pires Machado Portela, Antônio Rangel Torres Bandeira, Salvador Henrique de Albuquerque, Antônio Vitrúvio Pinto Bandeira e Acioli de Vasconcelos e José Soares Azevedo - de origens e posições sociais distintas, havendo desde um filho de família tradicional da zona canavieira, até um professor. O que eles tinham em comum era o gosto pelas letras e pelos estudos históricos, além do forte desejo de que a

\footnotetext{
${ }^{12}$ A visitação ao museu teve início em 1866, funcionando inicialmente como um verdadeiro "gabinete de curiosidades". Este funciona até os dias atuais. (SOUZA, 2010)
} 
História de Pernambuco fosse preservada, estudada, divulgada e valorizada, pelos próprios pernambucanos e pelos brasileiros em geral. Ou seja, com a fundação do sodalício, eles pretendiam fazer um resgate da história local, buscando um lugar de destaque à província na escrita da história nacional. Com isso, Pernambuco poderia retomar para si a legitimidade e importância no contexto político imperial. No dizer de Machado Portela, o IAGP deveria produzir conhecimento histórico na perspectiva regional: “(...) evitando que tais preciosidades se percam, ou que mão estranha e parcial proceda a sua exploração, de modo para nós talvez inglório (...) por ser mais fácil e exata a sua investigação e verificação de fatos no próprio teatro em que aconteceram" (SOUZA, 2010:32).

Já no final do século XIX, com o advento da República, tanto o IHGB quanto o IAGP buscaram redimensionar as suas tradições históricas, para que elas se adequem aos novos preceitos político vigentes no país. Porém, era preciso estabelecer uma transição segura de uma memória imperial para uma republicana, havendo a necessidade de se produzir narrativas que harmonizassem o passado colonial com o presente. Neste contexto, o sodalício pernambucano prosseguiu com o seu objetivo inicial de trazer visibilidade nacional para a História de Pernambuco, construindo a ideia de uma tradição republicana no Estado, na intenção de que os seus símbolos, personagens e eventos, ingressassem ao panteão da história oficial.

O discurso histórico formulado pelo IAGP era divulgado por meio de sua revista, que iniciou sua circulação em 1863 com poucos anos de intervenção. A Revista do IAGP, em seus anos iniciais, era trimestral, tendo a sua publicação limitada, de forma que eram publicadas apenas as atas de sessão ordinárias e extraordinárias, discursos e relatórios do presidente e dos secretários. No entanto, com o passar do tempo e com o aperfeiçoamento das pesquisas, ela passou a contar com artigos monográficos assinados, que vinham em edições menos frequentes, já que a revista passou a ser publicada anualmente. Podemos arriscar a falar que esta revista estava direcionada à elite intelectual, sendo provável que não fosse comercializada, já que não há em suas edições nenhuma inscrição de preço, e sim distribuída ao grupo de sócios e colaboradores que financiavam ou articulavam politicamente o financiamento de sua publicação. Nela colaboraram figuras de grande respaldo da intelectualidade brasileira, como: Capistrano de Abreu, Nina Rodrigues, Oliveira Lima, José Hygino Duarte Pereira, Barbosa Lima Sobrinho, José Antonio Gonçalves de Mello, Evaldo Cabral de Mello, Alfredo de Carvalho, Pereira da Costa, entre outros. 
Ao tratarmos da Revista do IAGP, não podemos nos esquecer das contribuições de Mário Melo, que, desde que se associou à instituição, nunca deixou de publicar seus textos nela, de maneira que, em todas as edições de 1909 a 1959 há publicações dele. Acreditamos que essa frequência não ocorre por acaso, pois, ainda em 1910, este historiador passou a compor a "Comissão de Estatuto e Redação da Revista", juntamente com Henrique Capitulino e Regueira Costa, ficando com o encargo até seus últimos dias de vida. Ou seja, ele passou a efetuar a função de editor, sendo esta uma função decisiva na produção da revista.

Mário Melo foi representado como um intelectual que sempre se dedicou à empreitada de contar a História de Pernambuco e de seus antepassados, na intenção de que esta não fosse esquecida e que fosse disseminada pelas novas gerações. Sobre isso, expõe Valdemar de Oliveira: “Onde houve um gesto patriótico a enaltecer, uma relíquia a preservar, um agravo a repelir, o que quer que fosse relacionado ao passado, ao presente ou ao futuro de Pernambuco, aí estava Mário Melo, pronto na defesa, pertinaz na resistência, ágil no ataque" (PARAÍSO, 1997: 24).

Ele foi um historiador de seu tempo, respirando as concepções históricas que permeavam o Brasil na primeira metade do século XX. Influenciado pelo pensamento positivista e metódico, movimentos que marcaram a produção histórica brasileira na época, buscando, através de incansáveis análises das fontes históricas, a "verdade" sobre o acontecimento passado. Além disso, primava pela valorização de uma concepção de história voltada aos eventos políticos, de forma que deveria ser ressaltada a biografia dos "grandes homens" e eventos que marcaram o percurso histórico. Assim, foram basicamente estas ideias que inspiraram as práticas dos institutos históricos brasileiros, durante o século XIX e as primeiras décadas do século XX, período em que estas instituições tinham a função de construir uma nova História do Brasil tendo como princípios políticos os ideais republicanos.

Porém, sabemos que cada instituto histórico espalhado pelo Brasil buscou legitimar o Estado que representava ao propor criar essa nova História para o país, valorizando certos personagens e eventos históricos que correspondessem à história local. Criou-se, assim, uma disputa simbólica entre os institutos históricos na intenção de que os seus ícones entrassem para o panteão da história oficial. Nesse contexto, o que marcou fortemente a produção histórica de Mário Melo foi o fato de ele estar vinculado ao Instituto História pernambucano, de maneira que investia na valorização da história de Pernambuco. Portanto, inserido no IAGP, lugar de sociabilidade que pretendia atuar 
como o lócus central de preservação dos vestígios do passado e construção dos saberes históricos de Pernambuco em favor da legitimação e valorização da história do estado no contexto político nacional, Mário Melo produziu suas narrativas históricas, aderindo à batalha empreendida pelo Instituto, uma verdadeira militância na intenção de que os ícones do passado pernambucano ingressem ao panteão da história nacional e para que não fossem esquecidos.

A produção historiográfica de Mário Melo estava presente tanto na grande imprensa, isto é, nos periódicos mais variados, nas páginas da revista do IAHGP, e também em alguns livros. Como salienta Cláudio Tavares, um dos seus biógrafos, ele publicou cerca de 50 volumes: “(...) a maioria sobre história, e história de Pernambuco, e que em cerca de cem mil artigos publicados durante sessenta anos de jornalismo, vamos encontrar, também, aí, grande percentagem de trabalhos de cunho histórico" (TAVARES, 1976: 60).

Sendo assim, nota-se a sua vasta produção e a impossibilidade de uma investigação a fundo e minuciosa dela, no entanto, acredita-se que o que se pode fazer é uma análise geral de suas narrativas na busca por tentar entender o que seria para ele o ofício do historiador e que história ele deveria contar.

Antes de iniciar as análises de seus textos históricos, faz-se necessário uma pequena explanação do principal lócus onde estas narrativas estavam presentes, isto é, a revista do IAGP. Esta era publicada periodicamente, com edições anuais ou de dois em dois anos, destinada a um pequeno público do Recife, arriscando falar que ela estava direcionada à elite intelectual, sendo provável que não fosse comercializada, já que não há em suas edições nenhuma inscrição de preço, e sim distribuída ao grupo de sócios e colaboradores que financiavam a sua publicação. Em 1910, esta revista passou a ser organizada por Mário Melo, quando se torna $1^{\circ}$ Secretário da instituição, compondo a "Comissão de Estatuto e Redação da Revista", assim, tudo o que seria escrito para ser editado na revista passaria por seu crivo de aprovação, sendo seu papel decisivo na produção dela.

Para dar o primeiro exemplo da concepção histórica de Mário Melo expõe-se fragmentos de um dos seus artigos para a revista do IAGP, de volume XXXI em 1931, com o título Frei Caneca, demonstrando o ímpeto do historiador, compartilhado entre os demais sócios da instituição, em afirmar os valores cívicos republicanos e democráticos presentes no passado pernambucano, ressaltando as prioridades do estado frente aos ideais de República. Neste texto, ele reverenciou a Revolução de 1817, um 
dos eventos históricos mais ressaltados por ele em toda a sua produção, tentando desmembrar as memórias relacionadas ao Império e ao imperador, apresentando a batalha simbólica que havia entre os cânones monárquicos e os republicanos que estavam se estabelecendo.

O entusiasmo dos brasileiros pelo príncipe dom Pedro foi efêmero. Em Pernambuco, com especialidade, a corrente nacionalista era republicana. Estavam vivas as feridas abertas em 1817 e não se extinguira o fermento revolucionário vitorioso de 1821 quando o imperador dissolveu a constituinte e pretendeu impor um presidente de Província contra a vontade do povo, em substituição daquele remanescente de 1817, eleito pelo povo (MELO. 1931b:10).

Ainda enfatizando a prioridade de Pernambuco frente aos novos ideais que emergem no século XX com a República, Mário Melo escreve no volume XXVIII da revista do IAGP, em 1927, um texto chamado "Pernambuco pioneiro no descobrimento", onde ele destacou o estado em vários sentidos, focando, principalmente, as prioridades pernambucanas com relação aos estudos da medicina.

Primeiro no descobrimento, primeiro nas letras, primeiro na formação da nacionalidade, primeiro na medicina. (MELO, 1927b: 305)

Fica assim, Pernambuco integrado como berço da medicina brasileira, quer por ter sido o primeiro campo experimental dos nossos colonizadores, quer por ter sido o primeiro rincão da América portuguesa que deu ao mundo um discípulo de Hipocrates (MELO. 1931b: 10)

Em quase todos os seus textos, Mário Melo buscou dar legitimidade ao que declarava, expondo que suas ideias eram compartilhadas com os outros historiadores brasileiros, sendo estes vinculados ao IAGP ou não, sempre citando algum deles:

O meu saudoso mestre e amigo J. B. Regueira Costa era dessa plenitude que exalça, por todos os meios, a sua terra natal. Para ele, Pernambuco acima de tudo; sempre pioneiro em todos os ramos. (MELO, 1927b: 305)

Pereira da Costa, baseado no foral da Carta de Olinda, consigna a chegada de Duarte Coelho a 9 de março de 1535, seu desembarque no porto do Marco a que outrora chamavam Pernambuco, a luta contra o gentil como a escreveu 
Jaboatão, a vitória a 27 de setembro e a providência imediata para a fundação da vila e da igreja de Igaraçu (MELO, 1928-1929: 68).

Outra grande característica de seus textos históricos, como já foi dito, é a sua luta constante para a preservação do passado "heroico" pernambucano, para que ele não caísse no esquecimento. Nesse fragmento da narrativa As Heroínas de Tejucopapo, presente no volume XXVIII da Revista do IAGP, percebemos que Mário Melo fez um forte apelo ao Instituto para que ele se posicionasse perante aos poderes públicos, na exigência de um monumento que lembrasse a bravura das mulheres da região contra as investidas holandesas.

Fácil, como está ainda, a localização do lugar da trincheira, em Tejucopapo, proponho que o Instituto Arqueológico se dirija aos poderes públicos do município de Goiana, a cujo território pertence, pedindo-lhes que, ao centro do antigo reduto, façam levantar um monumento, por mais modesto que seja - uma pirâmide de granito, um bloco rude de qualquer rocha ígnea - com a seguinte inscrição, para a memória eterna do feito: “Aqui, a 24-IV-1646, as mulheres de Tejucopapo conquistaram o tratamento de heroínas, por terem com as armas, ao lado dos maridos e dos filhos, repelido três assaltos de 600 holandeses que recuaram derrotados.” Mário Melo (MELO, 1927a: 335)

Essa batalha pela conservação da memória tradicional do estado pode ser vista tanto nos seus escritos na Revista do IAGP, como também nas páginas dos jornais. Nas análises de alguns de suas narrativas históricas para a sua coluna diária "História em Pequenas Doses", no jornal Folha da Manha ${ }^{13}$, que vigorou durante os anos 1940, pode-se perceber que estão presentes as reivindicações de Mário Melo para que a história de Pernambuco fosse lembrada pelos jovens: "Temos imprescindível necessidade, neste momento de apreensões, quiçá de perigos, de recordar feitos como o dos Guararapes, para que a mocidade brasileira se orgulhe de seus antepassados e, se preciso, na bravura os imite" (MELO, 1941d: s/p)

Além disso, também foi constatada a utilização de documentação histórica tida como oficial para provar o que alegava, isto é, ele primava pela descrição das fontes que provavam o que declarava. Isso era muito frequente nos seus textos, e, mesmo

\footnotetext{
13 "Com a amizade que ele dedicava ao governador Agamenon Magalhães, ali colaborou durante vários anos, de 1938 a 1957” (PARAÍSO, 1997: 58)
} 
escrevendo para veículos de grande disseminação de ideias, como os jornais, Mário Melo procurou construir seu métier histórico da forma mais científica possível, não fazendo distinções entre as suas narrativas históricas. Ou seja, Mário Melo não simplificava a produção de suas narrativas por elas estarem inserida em um meio popular, ao contrário, buscou deixar clara sua atuação como jornalista e historiador, escrevendo diariamente suas narrativas históricas, tanto na revista especializada como na imprensa de grande circulação:

Em fase da documentação inédita existente em Lisboa, pude provar de modo definitivo, segundo o parecer da comissão que estudou meu trabalho, que houve rebeldia republicana em 1710, por parte dos olindenses (MELO, 1941b: s/p)

Arquivos autênticos, insofismáveis, recentemente descobertos no Arquivo Histórico Colonial de Lisboa e publicado por Ernesto Enes, provam que Zumbi morreu na luta, sendo-lhe cortada a cabeça e remetida para aqui (MELO, 1941a: s/p)

Além disso, outro ponto observado nos textos de Mário Melo é o uso da narrativa histórica para tratar de problemas e reivindicações contemporâneas, não deixando o pretérito estático, e sim o trazendo para o presente, tentando passar para seus leitores as permanências da História. Ele fez isso na intenção de lutar pela preservação das tradições do passado pernambucano, sempre questionando os poderes públicos, através da legalidade, para que o peso da modernidade não derrube nosso passado.

Que, ao menos, pelo círculo de ferro da lei, haja entre nós um pouco de respeito pela tradição e cesse essa mania destruidora dos insensatos que obsecado (sic) por um futurismo abjeto, irracional, deturpador, vão quebrando todos os alicerces de nossa civilização, derrubando todas as colunas de nossas tradições (MELO, 1924: s/p)

A nova divisão territorial, principio por que se batiam os líderes de 1848 e pelo qual muitos deram a vida, numa alta compreensão de brasilidade, é problema que ocupa nossa atenção ainda hoje e que, sem necessidade de emprego de armas, deve-se constituir-se em aspiração nacional, para grandeza do Brasil (MELO, 1941c: s/p). 
Seja por meio do jornalismo, ou pela produção no meio acadêmico, os historiadores pernambucanos da primeira metade do século $\mathrm{XX}$, criticaram um discurso histórico que legitimasse a vocação de Pernambuco para os ideais republicanos, compartilhando, assim, desses valores e ideologias entre si, criando um grupo, no qual o protagonista deste artigo se insere. Assim, Mário Melo, influenciado e munido dos princípios elaborados por esses intelectuais, principalmente aqueles vinculados ao IAGP, iria construir a sua trajetória intelectual permeando os espaços mais científicos e próprios do historiador aos mais "populares", onde a narrativa poderia ser mais independente das normas científicas pregadas pela Academia, além de ser um meio que poderia atingir um público mais amplo e diversificado.

Portanto, como deixar de ressaltar esta figura tão importante para a vida intelectual de uma cidade como o Recife, que, durante a primeira metade do século XX, era uma metrópole cultural de grande visibilidade no Brasil. Como não destacar a trajetória de um historiador que construiu seu métier histórico "sob os porões" do IAGP, instituição que tinha a função de ditar as regras da prática historiográfica e criar verdades. Foi neste Instituto que Mário Melo atuou durante 50 anos de sua vida no cargo de secretário perpétuo, tempo bastante para que seu discurso histórico se misture com o da instituição, e esse entrelaçamento o impulsionasse a reproduzir e disseminar nos jornais a história criada pelo IAGP.

Realizar uma pesquisa sobre Mário Melo é trazer à tona a trajetória de uma personalidade pública, que se manteve presente diariamente nas páginas dos jornais e na revista do IAGP na primeira metade do século XX, e que hoje é mantido no anonimato. Ele é lembrado apenas pelos integrantes da decadente instituição do IAHGP, - onde está um dos bustos construídos em sua homenagem, envolvo de poeira e teias de aranha - e porque seu nome está vinculado a uma avenida recifense. Além disso, tratar deste sujeito é também dar visibilidade a aspectos da trajetória do IAGP e sua constituição política, ressaltando a importância de sua revista como veículo de transmissão de uma cultura histórica que estava sendo formulada pela instituição. Falar de Mário Melo é trazer à tona um intelectual que sofreu de um amor crônico por seu estado, e que por isso se envolveu constantemente em polêmicas e discussões nas páginas dos jornais, defendendo um posicionamento sempre a favor da preservação e divulgação da história de Pernambuco, história essa que, com muito afinco, ajudou a construir.

Logo, este artigo pretende contribuir para a ampliação e o adensamento das discussões acerca de alguns conceitos que envolvem a problemática da trajetória 
intelectual, que tem grande relevância para os estudos voltados para a construção do pensamento social brasileiro. Além disso, pretende-se também contribuir para com os estudos sobre cultura política e cultura história no Brasil, já que Mário Melo, durante muito tempo de sua vida foi o "porta-voz" de um importante instituto histórico do país, auxiliando, assim, na construção de uma prática historiográfica bem singular desenvolvida pela instituição.

\section{Fontes}

MELO, Mário (1924). Relatório dos trabalhos de 1923, pelo $1^{\circ}$ Secretário Perpétuo. Revista do Instituto Arqueológico Geográfico Pernambucano. Recife, vol. XXVI, NS, pp.123-126.

(1927a). As Heroínas de Tejucopapo. Revista do Instituto Arqueológico Geográfico Pernambucano. Recife, vol. XXVIII, NS, pp. 131-134.

(1927b). Pernambuco pioneiro no descobrimento. Revista do Instituto Arqueológico Geográfico Pernambucano. Recife, vol. XXVIII, NS, pp. 131-134. (1928-1929). A Igreja mais antiga do Brasil. Revista do Instituto Arqueológico Geográfico Pernambucano. Recife, vol. XXIX, NS, pp. 135-142. (1931a). Dentro da história. Rio de Janeiro: Companhia Editora Nacional. (1931b). Frei Caneca. Revista do Instituto Arqueológico Geográfico Pernambucano. Recife, vol. XXXI, NS, pp. 147-150.

(1941a). [o suicídio de Zumbi]. A história em pequenas doses. Folha da Manhã. Recife, 17 mar.

(1941b). [prova que houve rebeldia republicana na revolução de 1710]. A história em pequenas doses. Folha da Manhã. Recife, 16 jun.

(1941c). [revolução praieira]. A história em pequenas doses. Folha da Manhã. Recife, 02 jan.

(1941d). [terceiro centenário das duas batalhas do Guararapes]. A história em pequenas doses. Folha da Manhã. Recife, 11 jun. 1941.

(1953). Síntese das Atividades do Instituto Arqueológico de 1953. Jornal do Commercio. Recife.

\section{Referências Bibliográficas}

ANDERSON, Benedict (2008). Comunidades imaginadas. 2 ed. São Paulo: companhia das Letras.

BALANDIER, Georges. Antropología Política. Barcelona: Flamma, 1969.

CANTARELLI, Rodrigo. (2012). Contra a conspiração da ignorância com a maldade: A Inspetoria Estadual dos Monumentos Nacionais e o Museu Histórico e de Arte Antiga do estado de Pernambuco. 2012. Dissertação (Mestrado) - Programa de Pós-Graduação em Museologia e Patrimônio, UNIRIO/MAST, Rio de Janeiro. Disponívelem:<http://revistamuseologiaepatrimonio.mast.br/index.php/ppgpmus/article/ viewFile/269/211>. Acesso em: 06 de nov. 2015.

CARVALHO, José Murilo de (1990). A formação das almas: o imaginário da República no 
Brasil. São Paulo: Companhia das Letras.

CATROGA, Fernando (2005). Nação, Mito e Rito: religião civil e comemoralismo (EUA, França e Portugal). NUDOC-UFC. Fortaleza.

(2010). "O Culto dos mortos como uma poética da ausência". ArtCultura. Uberlândia, vol. 12 , n. 20. pp. 163-182.

CHUVA, Márcia (2009). Os Arquitetos da Memória. Sociogênese das práticas de preservação do patrimônio cultural no Brasil (anos 1930-1940). Rio de Janeiro: Editora UFRJ.

ELIAS, Norbert (2006). "Processos de formação de Estados e construção de nações". In: NEIBURG, Federico Neiburg \& WAIZBORT, Leopoldo Waizbort (Orgs.). Escritos \& ensaios; 1: Estado, processo, opinião pública. Rio de Janeiro: Jorge Zahar, pp. 153-165.

FONSECA, Homero (2001). Perfil parlamentar século XX: Mário Melo: a arte de viver teimosamente. Assembléia Legislativa do Estado de Pernambuco. Recife.

GOMES, Angela de Castro (2009). A República, a História e o IHGB. Belo Horizonte, MG: Fino Traço.

(2007). Cultura política e cultura histórica no Estado Novo. In: ABREU, Martha; SOIHET, Raquel; GONTIJO, Rebeca (org.). Cultura política e leituras do passado: historiografia e ensino de história. Rio de Janeiro: Civilização Brasileira, pp. 44-64. (1996). História e historiadores. Rio de Janeiro: Editora Fundação Getúlio Vargas.

MICELI, Sergio (2001). Intelectuais à brasileira. São Paulo: Companhia das Letras.

NASCIMENTO, Luis do. (2012) "Roteiro jornalístico de Mário Melo". In: BARBOSA, Virgínia; GASPAR, Lúcia. Mário Melo 1884-1959: uma bibliografia. Recife: FUNDAJ.

NASCIMENTO, Luis do (1968). Historia da Imprensa de Pernambuco.vol. 1. 2 ed. Recife: UFPE. Ed. Imprensa Universitária.

PARAÍSO, Rostand (1997). Cadê Mário Melo... Recife: Comunigraf.

RIBEIRO, Mariana dos Santos (2011). “O IHGB, O IAGP e as comemorações do centenário da República de 1817”. In: RIBEIRO, Mariana dos Santos. Construindo Histórias e Memórias: $O I H G B$ e o IAGP em meio às celebrações dos centenários do movimento pernambucano de 1817. Rio de Janeiro: PUCRio, set., pp. 192-269 Disponível em: <http://www.maxwell.lambda.ele.puc-rio.br/acessoConteudo.php?nrseqoco=67994>. Acesso em: 10 Mai. 2015.

TAVARES, Cláudio (1976). Mário Melo - jornalista e historiador democrata. Recife: Associação da Imprensa de Pernambuco.

SCHWARCZ, Lilia Moritz (2011). O espetáculo das raças: cientistas, instituições e questão racial no Brasil - 1870-1930. São Paulo: Companhia das Letras.

SIRINELLI, Jean-François (1996). Os intelectuais. In: RÉMOND, René (Org.). Por uma história política. Rio de Janeiro: EdUfrj / Editora da Fundação Getúlio Vargas, pp. 231369.

SOUZA, George Félix Cabral de (2010). Instituto Arqueológico, Histórico e Geográfico Pernambucano: breve história ilustrada. Recife: IAHGP.

Artigo recebido em 31 de agosto de 2015.

Aprovado em 08 de março de 2016.

DOI: $10.12957 /$ intellectus.2016.23842 